\title{
HEAT EXCHANGE AND SURFACE CONDITIONS IN NORTH WATER, NORTHERN BAFFIN BAY
}

by

\author{
K. Streffen AND A. Ohmura
}

Department of Geography, Swiss Federal Institute of Technology, CH-8057 Zürich, Switzerland

\section{ABSTRACT}

North Water is situated in the high Arctic between Greenland and Canada $\left(74^{\circ}-79^{\circ} \mathrm{N}, 70^{\circ}-78^{\circ} \mathrm{W}\right)$. The sea surface of this region has no homogeneous ice cover during the winter and spring months, due to the occurrence of polynyas.

The results of the heat balance and the airborne remote sensing over North Water during winter are reported. The heat balance investigation was concerned with the identification of heat sources and their magnitudes. The remote sensing was aimed at determining the sea surface temperature and clarifying the exact nature of the surface of North Water in winter.

North Water was found to be mostly covered with new and young ice and probably devoid of first year ice until March. The surface was about $20^{\circ} \mathrm{C}$ warmer than that of the surrounding fast ice. The warmest areas were frequently located in Smith Sound, Lady Ann Strait and around the Carey Islands. Open water patches above freezing point, ranging from $-1.5^{\circ} \mathrm{C}$ to $-0.1^{\circ} \mathrm{C}$ were of ten found along the west coast of Greenland.

The surface of North Water receives heat from the sea water during winter between October and March at the rate of $15 \mathrm{MJm}^{-2} \mathrm{~d}^{-1}$ of which $80 \%$ and $20 \%$ are from enthalpy contained in sea water and latent heat of fusion released as the surface water freezes, respectively. The basic difference in winter heat balance between North Water and other ice covered arctic seas is the magnitude of the enthalpy supplied by the seawater which is $9 \mathrm{MJm}^{-2} \mathrm{~d}^{-1}$ larger for the North Water. This is the main heat source, which keeps the surface from becoming solidly frozen.

\section{INTRODUCTION}

The sea surface at the northern end of Baffin Bay between Hayes Peninsula in northwestern Greenland and Ellesmere and Devon Island in the Queen Elizabeth Islands, NWT, (Figure 1) has been reported to lack substantial sea ice concentration or even to be open during winter, and is called North Water.

The main objectives and the scope of operation of the North Water Project have been described by Müller and others (1973). The unusually mild climate of the region of North Water was described by Ohmura $(1975,1976 \mathrm{a}, 1978)$ Sea ice conditions were evaluated by Ito (1982) for light half-years based on LANDSAT imageries. Comprehensive work on the sea ice conditions during winter was recently presented by Steffen (1984).

The objectives of the present article are to report on (1) the surface conditions of North Water (distribution of sea ice and open water, surface characteristics of sea ice) and (2) the surface heat budget.

\section{SURFACE CONDITIONS}

Method

To cover the area of about $80,000 \mathrm{~km}^{2}$ in dark winter required thermal channel measurements either from satellites or from an aircraft. Thermal measurements from satellites were considered inappropriate, as their acuracy and resolution were not compatible for the present purposes. A low-flying aircraft was chosen as an instrument platform.

The thermal radiation from the sea surface was measured with a Precision Radiation Thermometer (PRT-5)

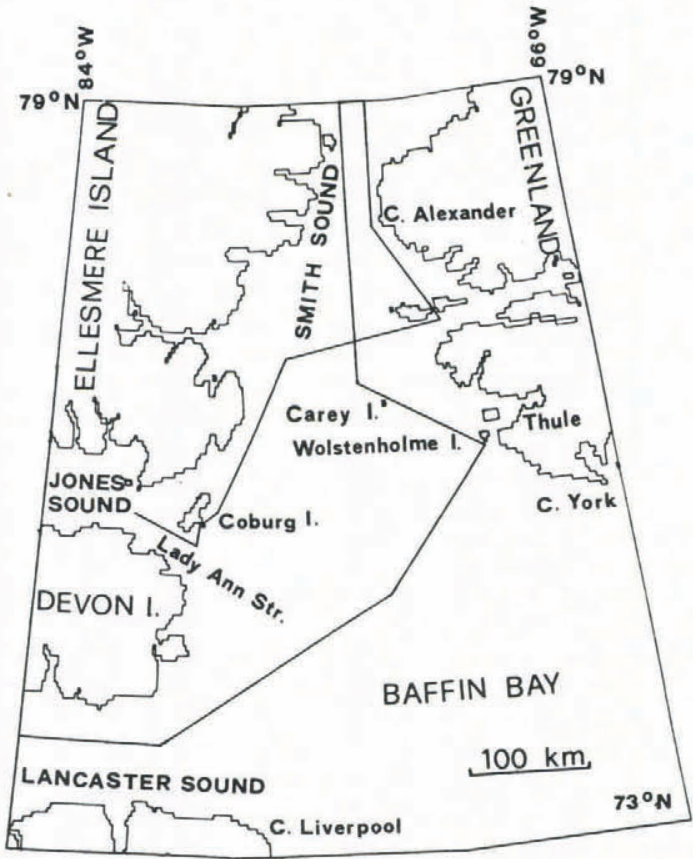

Fig.1. Map of North Water region and flight profiles.

in the spectral range from 9.5 to $11.5 \mu \mathrm{m}$ from a flight altitude of $300 \mathrm{~m}$. The $20^{\circ}$ angle-of-view was chosen which gave a circular field-of-view with a $100 \mathrm{~m}$ diameter. At the same time, the ground along the flight path was filmed on Ektachrome Videonews High Speed film to obtain pictorial information on the surface characteristics of sea ice and open water and also to aid locating the aircraft's position. A Spectrolamp SX-16 searchlight with an average beam power of 25,000 Lumen served as a source of illumination. The instruments were installed vertically through a hatch in the bottom of a Twin Otter aircraft, which was flown at an average airspeed of $220 \mathrm{~km} / \mathrm{h}$. Air temperature at flight level was continuously measured for the subsequent atmospheric correction.

The raw brightness temperatures require a number of corrections, for the emissivities of water, snow and ice surfaces, for the absorption and emission by the atmospheric water vapour and for the multiple reflection of radiation between the cloud bottom and the ground. The accuracy of the corrected temperature is estimated at $\pm 0.15^{\circ} \mathrm{C}$ (Steffen 1982).

The flight path had a total length of $2300 \mathrm{~km}$ of which $2000 \mathrm{~km}$ were over North Water (Figure 1). NOAA-VHRR infrared satellite images were used for interpolation of the surface temperature between the flight profiles. Their grey-scale was calibrated with the aid of the low level infrared thermometry. From November 1978 until March 1979 and from December 1980 until March 1981, a total of fourteen low level remote sensing flights were carried out. The flight dates were chosen so that different 
meteorological circulation patterns over North Water and its sourroundings were represented.

\section{Surface temperature distribution}

Based on the surface temperature averaged over 20 $\mathrm{km}$ and with the aid of NOAA-VHRR infrared-images, fourteen surface isothermal maps were drawn, of which two are presented in Figure 2.

The isothermal maps indicate a temperature increase of $10^{\circ} \mathrm{C}$ to $15^{\circ} \mathrm{C}$ from west to east in the northern Baffin Bay and in Smith Sound. The highest sea surface temperatures are located in Smith Sound, west of Cape Alexander. Their range of $-1{ }^{\circ} \mathrm{C}$ to $-15^{\circ} \mathrm{C}$ for the $20 \mathrm{~km}$ means is $20^{\circ} \mathrm{C}$ warmer than the surrounding fast ice areas. This temperature anomaly was observed on all flight missions for the two winters $1978 / 79$ and $1980 / 81$. The area
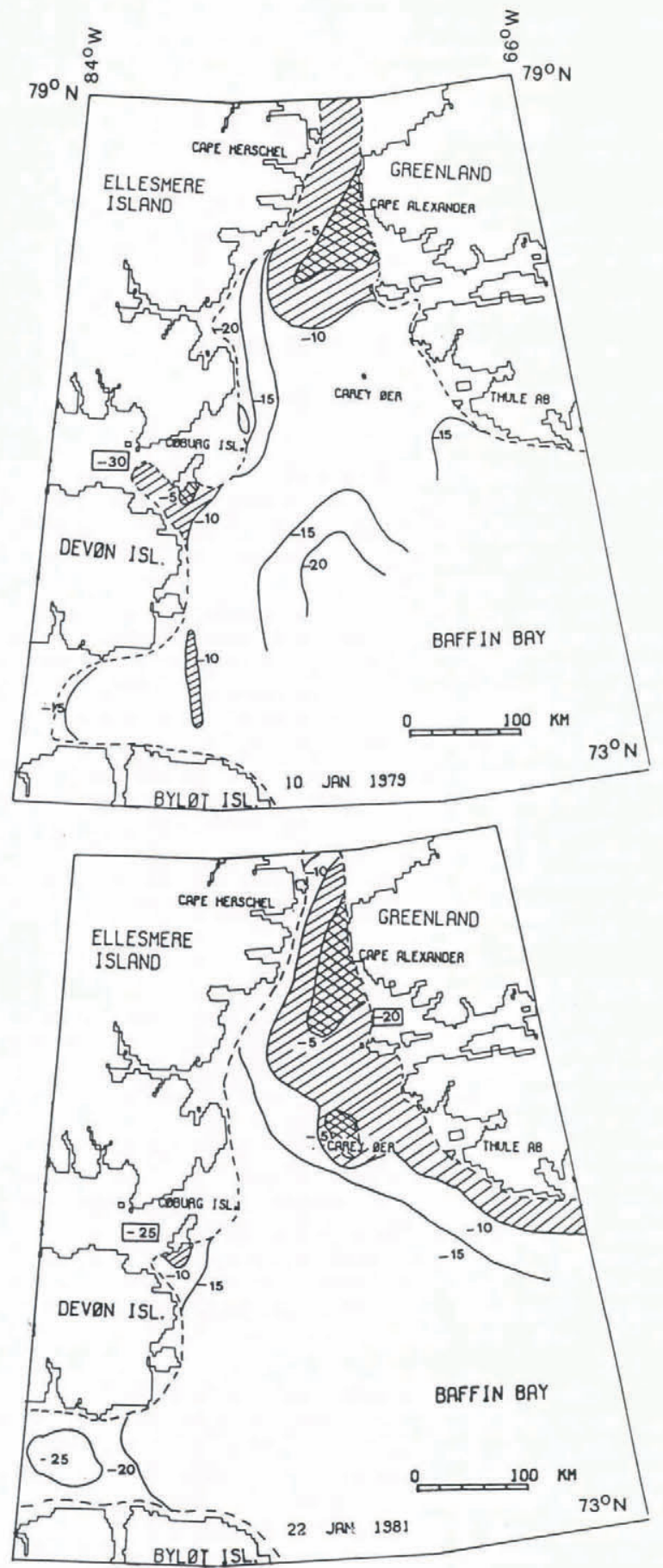

Fig.2. Isothermal maps of the North Water region base on low level infrared thermometry and NOAA-VHRR satellite interpretation. Upper : 10.1.79; Lower : 22.1.81.
TABLE 1. AREA OF THE TEMPERATURE ANOMALY WEST OF CAPE ALEXANDER DURING WINTER 1978/79 AND 1980/81 FOR VALUES HIGHER THAN $-5^{\circ} \mathrm{C}$.

$$
\text { Date Area }\left(\mathrm{km}^{2}\right) \text { Date Area }\left(\mathrm{km}^{2}\right)
$$

$\begin{array}{rrrr}12.11 .1978 & 0 & 2.12 .1980 & 5000 \\ 6.12 .1978 & 4200 & 20.12 .1980 & 1570 \\ 25.12 .1978 & 2400 & 29.12 .1980 & 700 \\ 10.1 .1979 & 3600 & 22.1 .1981 & 4000 \\ 5.2 .1979 & 0 & 7.1 .1981 & 0 \\ 24.2 .1979 & 1400 & 2.3 .1981 & 0 \\ 5.3 .1979 & 0 & 16.3 .1981 & 700\end{array}$

of the temperature anomaly for values higher than $-5^{\circ} \mathrm{C}$ varied up to $5000 \mathrm{~km}^{2}$, whereas no systematic decrease in areas was noticed during the winter (Table 1).

Another, but less pronounced, temperature anomaly is found in the vicinity of the Carey Islands. During the winter 1978/79 this anomaly occurred only sporadically. A third temperature anomaly is situated in the Lady Ann Strait, south of Coburg Island. Its dimension was less than $20 \mathrm{~km}$ in diameter and is therefore not clearly seen on the isothermal maps.

Ice conditions

A method was developed for calculating ice thickness based on the radiometric surface temperature and air temperature (Steffen 1984). This method enables one to estimate the ice thickness up to $50 \mathrm{~cm}$. Based on this method, the classification of these ice types was made along the flight profile - ice free, dark nilas, light nilas, grey ice, grey-white ice and white ice. Comparison of the thermal ice classification with the visual evaluation which was based on grey-tones of the aerial images, showed a deviation of only $3 \%$. From the profile measurements of the two winters $1978 / 79$ and $1980 / 81$, the following conclusion can be made: young ice, nilas and the ice free areas covered more than $50 \%$ of North Water in the months November to February. During this period, grey-white ice with an ice thickness of 15 to $30 \mathrm{~cm}$ was dominant. A large ice free area of $17 \%$ of the entire profile length was recorded only once, whereas on all the other flights only a few percent of ice free area was measured. In March, the last month of the investigation, white ice was dominant.

\section{Warm water cells}

The existence of warm water cells was discovered along the flight profile. The water surfaces with temperatures ranging from $-1.5^{\circ} \mathrm{C}$ to $-0.1^{\circ} \mathrm{C}$ were located in North Water mainly along the Greenland coast, in the vicinity of Wolstenholme Island, the Carey Islands and in Smith Sound. On the Canadian side these were found in Lady Ann Strait. The diameter of the warm water cells varied from a few hundred meters to $30 \mathrm{~km}$. The frequency distribution showed a maximum occurrence in the temperature range from $-1.0^{\circ} \mathrm{C}$ to $-0.8^{\circ} \mathrm{C}$ for December and January. Frequency of occurrence of warm water cells decreased towards spring. A detailed analysis of the regional distribution and the seasonal variation of the warm water cells is given in Steffen (1984). These measurements are evidence of upwelling warmer water, presumably of Atlantic origin, brought from the depth to the surface.

\section{HEAT EXCHANGE}

The method for heat exchange calculation for North Water is described in detail in Ohmura (1976b). Seasonal change in global radiation on North Water follows the common trend for the Arctic, in that global radiation is larger in spring than in autumn, when the months of similar solar elevation are compared. This is due to the higher surface albedo in spring. The albedo of the surface of North Water in February, the month of the return of 
TABLE 2. SUMMARY OF MONTHLY AND ANNUAL RADIATION COMPONENTS FOR NORTH WATER $\left(\mathrm{MJM}^{-2} \mathrm{MO}^{-1}, \mathrm{MJM}^{-2} \mathrm{YR}^{-1}\right)$ (DATA FROM OHMURA 1976B)

\begin{tabular}{|c|c|c|c|c|c|c|c|c|c|c|c|c|c|}
\hline & Jan & $\mathrm{Feb}$ & Mar & Apr & May & Jun & Jul & Aug & Sep & Oct & Nov & Dec & Year \\
\hline Global Radiation & PN & 12.1 & 144.2 & 425.5 & 724.4 & 798.8 & 644.1 & 374.9 & $181: 0$ & 23.0 & PN & PN & 3328. \\
\hline Albedo & - & 81 & 38 & 37 & 32 & 12 & 13 & 15 & 30 & 63 & - & - & 23 \\
\hline $\begin{array}{l}\text { Short-wave } \\
\text { reflected rad. }\end{array}$ & PN & -9.6 & -54.8 & -157.6 & $-232.0 \cdots$ & -95.7 & -83.6 & -56.4 & -54.3 & -14.6 & PN & PN & -759. \\
\hline Short-wave net rad. & PN & 2.5 & 89.4 & 267.9 & 492.4 & 703.1 & 560.5 & 318.5 & 126.7 & 8.4 & PN & PN & 2569. \\
\hline $\begin{array}{l}\text { Absorbed long-wave } \\
\text { incoming radiation }\end{array}$ & 528.8 & 429.3 & 487.8 & 480.7 & 667.5 & 738.2 & 830.6 & 804.7 & 714.4 & 615.3 & 551.8 & 537.1 & 7386. \\
\hline Surface emission & -674.2 & -576.8 & -628.7 & -637.5 & -767.0 & -811.3 & -882.0 & -859.4 & -770.4 & $-744 \cdot 5$ & $-683 \cdot 4$ & -682.6 & -8718. \\
\hline Long-wave net rad. & -145.4 & -147.5 & -140.9 & -156.8 & -99.5 & -73.1 & -51.4 & -54.7 & -56.0 & -129.2 & -131.6 & -145.5 & -1332 \\
\hline Net radiation & -145.4 & -145.0 & -51.5 & 111.1 & 392.9 & 630.0 & 509.1 & 263.8 & 70.7 & -120.8 & $-131 \cdot 6$ & -145.5 & 1238. \\
\hline
\end{tabular}

TABLE 3. MONTHLY AND ANNUAL HEAT BALANCE ON THE SURFACE OF NORTH WATER $\left(\mathrm{MJM}^{-2} \mathrm{MO}^{-1}, \mathrm{MJM}^{-2} \mathrm{YR}^{-1}\right)$ (DATA FROM OHMURA 1976B)

\begin{tabular}{lcccccccccccccccc} 
& Jan & Peb & Mar & Apr & May & Jun & Jul & Aug & Sep & Oct & Nov & Dec & Year \\
\hline Net radiation & -145.4 & -145.0 & -51.5 & 111.1 & 392.9 & 630.0 & 509.1 & 263.8 & 70.7 & -120.8 & -131.6 & -145.5 & 1238. \\
Sens. Heat Flux & -372.0 & -248.3 & -313.5 & -95.3 & -38.9 & 15.0 & 11.7 & 13.0 & -18.8 & -156.8 & -265.8 & -313.5 & -1783. \\
Lat. Heat Flux & -59.8 & -29.3 & -22.2 & -7.5 & -43.9 & -57.7 & -79.0 & -30.9 & -27.6 & -59.8 & -47.7 & -41.4 & -507. \\
Residual & 577.2 & 422.6 & 387.2 & -8.3 & -310.1 & -587.3 & -441.8 & -245.9 & -24.3 & 337.4 & 445.1 & 500.4 & 1052.
\end{tabular}

the sun, is so high that it is not much different from other regions in the Arctic. This is not only due to the higher sea ice concentration, but also due to the higher albedo of the open water surface for lower solar elevation. Although the sea ice concentration does not change significantly in the following two months, in March and April, the increase in solar elevation alone causes the substantial decrease in the albedo of the open water surfaces, resulting in a mean albedo of approximately $38 \%$ for the entire polynya. This value is about half of the surface albedo in the Central Polar Ocean and becomes the main reason for the positive net radiation already in April.

Long-wave radiation shows two distinctive regimes in the year. During the winter period between October and April, it is, on an average, $-5 \mathrm{MJm}^{-2} \mathrm{~d}^{-1}$. The long-wave net radiation increases rapidly in May and keeps a relatively high value of $-2 \mathrm{MJm}^{-2} \mathrm{~d}^{-1}$ until September. The winter value is mainly due to the large energy loss through the emission from the warm surface and the summer value is mainly caused by the large incoming radiation due to the larger cloud amount.

Because of the low surface albedo and the larger long-wave net radiation in summer, net radiation in this region ranges between two and three times that for the Central Polar Ocean. During the winter, however, larger cloud amount keeps the effective radiation loss of the surface only slightly higher than the pack ice regions. The total radiative energy gain of the surface between April and September amounts to $1978 \mathrm{MJm}^{-2}$, whereas the total loss between October and March is only $740 \mathrm{MJm}^{-2}$. Consequently, an annual net radiation of $1238 \mathrm{MJm}^{-2}$ was received at the surface. This is the largest annual net radiation within the Arctic Circle and comparable to that for the Norwegian Sea between Iceland and southern Norway.

The surface energy balance on the North Water is characterized by distinct winter and summer regimes. In winter a large amount of energy is carried by the sea water, more than half of which is used for direct heating of the overlying atmosphere. Since the polynya is a seasonal phenomenon prevailing in cold months, the energy exchange in the winter regime is described below.

The supply of heat from the sea water begins in October. The supply increases steadily and reaches its maximum in January. During the six months between
October and March the subsurface heat supply runs at 15 $\mathrm{MJm}^{-2} \mathrm{~d}^{-1}$. At the height of the winter in January, the rate peaks at $19 \mathrm{MJm}^{-2} \mathrm{~d}^{-1}$. These values are slightly higher than those for the Norwegian Barents Sea evaluated by Vowinckel and Orvig (1966).

The rate of the sea ice formation in the region of North Water is being investigated through remote sensing missions and sea ice thickness measurements. The supply of heat by refreezing is estimated at most at $3 \mathrm{MJm}^{-2} \mathrm{~d}^{-1}$. The remaining $12 \mathrm{MJm}^{-2} \mathrm{~d}^{-1}$ or more must be withdrawn from the enthalpy in the sea water. During the same period, the release of enthalpy from the sea water is estimated at 3.0 to $3.3 \mathrm{MJm}^{-2} \mathrm{~d}^{-1}$ for the pack ice region in the Central Polar Ocean (Vowinckel and Orvig 1966) and also for most of Baffin Bay (Walmsley 1966). Therefore, the difference in heat release by the sea water between the North Water and other ice-covered sea surfaces in the Arctic is in the order of $9 \mathrm{MJm}^{-2} \mathrm{~d}^{-1}$.

\section{CONCLUSIONS}

In contradiction to earlier reports, the surface of North Water is very rarely open in winter. The surface is covered by new and young ice and lacks first year ice until March. The average sea surface temperature is about $20^{\circ} \mathrm{C}$ higher than that of the surrounding fast ice. The warmer, hence ice-poor areas were found in Smith Sound, Lady Ann Strait and around the Carey Islands. The temperature in Smith Sound tends to be warmer on its eastern half, ie nearer to Greenland. Open water cells at above freezing temperature were of ten found in the new ice rich area and located most frequently along the Greenland coast. The surface temperature of such cells ranged from $-1.5^{\circ} \mathrm{C}$ to $-0.1^{\circ} \mathrm{C}$ with the highest frequency between $-1.0^{\circ} \mathrm{C}$ and $-0.8^{\circ} \mathrm{C}$.

The surface of North Water receives heat from the sea water during the six winter months between October and March at the rate of $15 \mathrm{MJm}^{-2} \mathrm{~d}^{-1}$. The heat flux reaches the years maximum of $19 \mathrm{MJm}^{-2} \mathrm{~d}^{-1}$ in January. Twenty percent of the oceanic heat flux is due to the freezing of sea water and the remaining $80 \%$ is due to supply of enthalpy from the warmer sea water. The latter is therefore, the main heat source and is about $9 \mathrm{MJm}^{-2} \mathrm{~d}^{-1}$ larger than in ice covered arctic seas. Because of this supply of oceanic heat, the surface of North Water is kept from becoming solidly frozen over. The exact oceanographic 
mechanism of the heat supply is still unknown. The discovery of warm water cells, however, suggests the existence of a number of convective cells at least in the layer near the surface.

\section{ACKNOWLEDGEMENTS}

Generous logistic support was provided by Polar Continental Shelf Project of Department of Energy, Mines and Resources of Canada through Dr G. Hobson. Financial support for this work was provided by Government of Canada (Contract No OSU76-00151), US National Science Foundation (Contract No DPP-7826132), Swiss National Science Foundation (Contract No 2.807-0.77) and Petro Canada, LDT, Calgary, Canada.

\section{REFERENCES}

Ito H 1982 Sea ice atlas of Northern Baffin Bay. Zürcher Geographische Schriften 7, Zürich, Department of Geography, Swiss Federal Institute of Technology

Müller F, Ohmura A, Braithwaite R J 1973 Das North Water Projekt (kanadisch-grönländische Hocharktis). Geographica Helvetica 28(2): 111-117

Ohmura A 1975 The climate of North Water 1972-75 (Part I). In Müller F (ed) North Water Project, Progress Report III. Zürich, ETH-Zürich and McGill University: $14-54$

Ohmura A 1976a The climate of North Water 1972-76 (Part II). In Müller F (ed) North Water Project, Progress Report IV. Zürich, ETH-Zürich and McGill University: $9-40$

Ohmura A 1976b Radiation and heat balance on the surface of North Water. In Müller F (ed) North Water Project, Progress report IV. Zürich, ETH-Zürich and McGill University: 41-54

Ohmura A 1978 The climate of North Water 1972-76 (Part III). In Müller F (ed) North Water Project, Progress Report V. Zürich, ETH-Zürich and McGill University: $10-22$

Steffen K 1982 Sea ice classification from infrared thermometry over the North Water, Winter 1980/81. International archives of ISPRS 24(VII/1): 767-776

Steffen K 1984 Oberflächentemperatur einer arktischen Polynya: North Water im Winter. PhD Thesis, Department of Geography, Swiss Federal Institute of Technology

Vowinckel E, Orvig S 1966 Energy balance of the Arctic, heat budget over the Arctc Ocean. Archiv für Meteorologie, Geophysik und Bioklimatologie 14(3-4): 303-325

Walmsley J L 1966 Ice cover and surface heat fluxes in Baffin Bay. Publication in Meteorology 84, Montreal, Arctic Meteorology Research Group, McGill University 